\title{
Valsts policijas darbinieka profesionālās ētikas pamatprincipi
}

\author{
Dr. iur. Ëriks Trels \\ Rīgas Stradina universitāte, Juridiskā fakultāte, Latvija \\ Valsts policijas koledža, Policijas tiesību katedra, Latvija \\ eriks.trels@gmail.com
}

\section{Kopsavilkums}

2020. gada 5. februārī tika pieṇemts jauns Valsts policijas ētikas kodekss. Rakstā tiks analizēti profesionālās ētikas pamatprincipi, kuri jāievēro Valsts policijas darbiniekiem, gan pildot dienesta pienākumus, gan arī ārpus dienesta pienākumu izpildes vietas un laika. Tiks analizēta arī normatīvā regulējuma, kas nosaka Valsts policijas darbinieka profesionālās ētikas pamatprincipus, vēsturiskā attīstîba laika posmā no 2005. gada un līdz mūsdienām.

Atslēgvārdi: Valsts policija, Valsts policijas darbinieks, profesionālā ètika, ētikas pamatprincipi.

\section{levads}

Valsts pārvaldes iekārtas likums nosaka, ka Valsts pārvalde darbojas visas sabiedrības interesēs, vienlaikus ievērojot privātpersonas tiesības un tiesiskās intereses, kā arī cilvēktiesības [6]. Realizējot šajā likumā tam piešḳirtās pilnvaras, Ministru kabinets 2018. gada 21. novembrī pieñēma ieteikumus "Valsts pārvaldes vērtības un ètikas pamatprincipi", kuros ierosināja Valsts pārvaldē ievērot šādus ētikas pamatprincipus: profesionalitāti un efektivitāti; godprātību; atbildību; darbu sabiedrības labā; valsts ilgtspēju un sabiedrības labklājību; atklātu un sabiedrībai pieejamu valsts pārvalde; sadarbību valsts pārvaldē [8]. 2020. gada 5. februārī tika pieṇemti Valsts policijas iekšējie noteikumi "Valsts policijas ètikas kodekss", kuros ir iekḷauti vairāki ētikas pamatprincipi, kas jāievēro Valsts policijas amatpersonām ar speciālajām dienesta pakāpēm (turpmāk - Valsts policijas darbinieks), darbiniekiem, ar kuriem noslēgts darba līgums, un valsts civildienesta ierēdṇiem (visas trīs grupas kopā turpmāk - nodarbinātais) [11]. Kaut arī noteikumos ir atrunāts, ka minētais normatīvais akts "nav visaptverošs ētikas vērtību, pamatprincipu un 
vispārējās uzvedības noteikumu apraksts" [11], tomēr tas nosaka pienākumu nodarbinātajiem ievērot septinus ētikas pamatprincipus: profesionalitāti; godprātību; objektivitāti; darbu sabiedrības labā; konfidencialitāti; atbildību; lojalitāti, kā arī piecas Valsts policijas vērtības: piederību; sadarbību; attīstību; cien,u; komunikāciju.

Tēmas aktualitāti nosaka gan izmainas normatīvajā regulējumā, gan Eiropas Savienības iestāžu ieteikumi, kas sekmēja normatīvā regulējuma attīstību. Eiropas Padomes Pretkorupcijas starpvalstu grupa (franču val. Groupe d'Etats contre la corruption, GRECO) savā ziṇojumā, kas tika publicēts 2018. gada 21. augustā, ir norādījusi, ka Latvijā Valsts policijai un Valsts robežsardzei ir jāizstrādā objektīvi un pārskatāmi kritēriji, lai novērtētu policijas un robežsardzes darbinieku atbilstību ētikas kodeksiem $[25,4]$. GRECO arī norādījusi, ka Valsts policijas un Valsts robežsardzes ētikas kodeksi "abās institūcijās vēl ir pienācīgi jāintegrē un darbiniekiem tie vēl ir jāapgūst. Informācija par ètikas noteikumu praktisku izpildi bija ierobežota un bieži vien pretrunīga, ko varētu skaidrot ar ievērojamām neatbilstībām attiecīgajā tiesiskajā regulējumā” [25, 35]. Lai atrisinātu šis un citas konstatētās problēmas, GRECO ieteica "i) pārskatīt ētikas kodeksus un ētikas komiteju noteikumus, lai nodrošinātu, ka saskan noteikumi un procedūras, kas lauj pārliecināties par atbilstību kodeksam, un ka tiek noteiktas sankcijas un procedūras par pārkāpumiem; un ii) nodrošināt, ka par ētikas kodeksiem un ši ieteikuma i) dal̦ā minētajiem mehānismiem to izpildei tiek organizētas apmācības, iesaistot attiecīgās ètikas komisijas" [25, 36]. Izpildot šos ieteikumus, tika veikti uzlabojumi normatīvajā regulējumā, no kuriem daḷa tiks analizēta šajā rakstā.

Darba mērḳis: analizēt normatīvo regulējumu, kas nosaka Valsts policijas darbinieka profesionālās ètikas pamatprincipus, sniegt skaidrojumus tajā izmantotajiem jēdzieniem, konstatēt iespējamus problēmjautājumus un piedāvāt tiem risinājumus.

Materiāls un metodes: temata analīze tiek veikta, izmantojot vispārīgās pētniecības metodes, piemēram, analīzi un sintēzi, salīdzināšanu un apkopojumu, cēloṇsakarību atklāšanu, kā arī tiesību normu interpretācijas metodes.

\section{Normatīvā regulējuma vēsturiskā attīstība}

Šajā nodaḷā, pētot normatīvā regulējuma vēsturisko attīstîbu, tiks analizēti un savstarpēji salīdzināti trīs iekšējie normatīvie akti, kas, cits citu nomainot, noteica, kādi profesionālās ètikas pamatprincipi jāievēro Valsts policijas darbiniekiem: 2005. gada 31. maijā pieñemtie Valsts policijas noteikumi Nr. 1 "Valsts policijas darbinieka profesionālās ètikas un uzvedības kodekss" (turpmāk arī - 2005. gada noteikumi), 2014. gada 16. septembrī pieñemtie Valsts policijas iekšējie noteikumi Nr. 36 "Valsts policijas ètikas kodekss" (turpmāk arī - 2014. gada noteikumi) un 2020. gada 5. februārī pieṇemtie Valsts policijas iekšējie noteikumi Nr. 3 "Valsts policijas ètikas kodekss" (turpmāk arī 2020. gada noteikumi).

Pirmais no minētajiem normatīvajiem aktiem no diviem turpmākajiem atšḳiras arī pēc sava nosaukuma - "Valsts policijas darbinieka profesionālās ètikas un uzvedības kodekss" [9]. Ši kodeksa 2. nodaḷā "Ëtikas pamatprincipi” tika iekḷauti pieci ètikas 
pamatprincipi: objektivitāte, profesionalitāte, godprātība, konfidencialitāte un atbildība. Jāatzīmē, ka starp noteikumu 5. punktā uzskaitītajiem ētikas pamatprincipiem un citiem 2. nodaḷa iekḷautajiem punktiem (6.-16. punkts) atšḳirībā no turpmākajos gados izstrādātajiem noteikumiem netika veidota tieša sasaiste.

Veicot minēto normatīvo aktu analīzi un salīdzinājumu, ir iespējams konstatēt, ka 2005. gada noteikumu 6. punkts, kas reglamentēja, ka "policijas darbinieks, pildot savus pienākumus, ievēro likumu un citu normatīvo aktu prasības, rīkojas objektīvi un taisnīgi, ar savu izturēšanos un rīcību veicinot sabiedrības uzticēšanos policijai” [9], ietver divus pamatprincipus: objektivitāti un godprātību.

Savukārt 2005. gada noteikumu 7. punkts, kas ietver jautājumu par cilvēktiesību ievērošanu un diskriminācijas nepiel̦aušanu, un 9. punkts, kas veltìts jautājumam par personas goda un cien̦as neaizskaršanu, 2014. gada un 2020. gada noteikumos tika iekḷauti nodalāa "Vispārējās uzvedības normas". 2005. gada noteikumu 8. punkts, kas noteica, ka "policijas darbinieks pastāvīgi paaugstina savu profesionālo kvalifikāciju" [9], ir profesionalitātes pamatprincipa sastāvdaḷa.

2005. gada noteikumu 10. punkts, kas pieškīira policijas darbiniekam tiesības lietot fizisku spēku, speciālos līdzekḷus un šaujamieroci, turpmākajos normatīvajos aktos, kas nosaka Valsts policijas darbinieka profesionālās ētikas normas, netika iekḷauts, jo ir reglamentēts likuma "Par policiju" 13. un 14. pantā [5]. Līdzīgi ir ar 2005. gada noteikumu 12. punktu, kas saskan ar likuma "Par policiju" 9. pantu "Policijas darbinieka vispārīgie pienākumi”.

Arī 2005. gada noteikumu 11. punktā ietvertais jautājums par spīdzināšanas, cietsirdīgas, necilvēcīgas un pazemojošas izturēšanās nepieḷaušanu netiek iekḷauts jaunākajos ètikas kodeksos, jo ir atrunāts vairākos ārējos normatīvajos aktos. Latvijas Republikas Satversmes 95. pants nosaka: "Valsts aizsargā cilvēka godu un ciennu. Spīdzināšana, citāda cietsirdīga vai cieņu pazemojoša izturēšanās pret cilvēku ir aizliegta. Nevienu nedrīkst pakḷaut nežēlīgam vai cilvēka cieṇu pazemojošam sodam" [1].

2005. gada noteikumu 13. un 14. punktā bija ietverts jautājums, kas saistīts ar personīga labuma gūšanas nepiel̦aušanu, un 2014. gada noteikumos tas ir iekḷauts kā apakšpunkts punktā, kas raksturo godprātības pamatprincipu, savukārt 2020. gada noteikumos tas ir ietverts 5. nodạ̣ā "Uzvedības noteikumi komunikācijā ar lobētājiem".

2005. gada noteikumu 15. punkts, kas noteica, ka "policijas darbinieks neizpauž viṇam zināmo dienesta informāciju, izṇemot likumos noteiktos gadījumos" [9], ir konfidencialitātes pamatprincipa sastāvdaḷa, savukārt 16. punkts, kas paredzēja, ka amatpersonai ir jāatbild par savu rīcību, ir ietverts atbildības pamatprincipā.

2014. gada 16. septembrī pieņemtie Valsts policijas iekšējie noteikumi Nr. 36 "Valsts policijas ètikas kodekss" papildināja Valsts policijas darbinieka profesionālās ètikas pamatprincipu saturu un strukturēja tos - katrā no pieciem punktiem (objektivitāte, profesionalitāte, godprātība, konfidencialitāte un atbildība) bija izveidoti vairāki apakšpunkti, kas izskaidroja punktos minēto pamatprincipu saturu. Šāds risinājums ir pozitīvi vērtējams, jo ḷāva izvairīties no atškirīigas pamatprincipu satura interpretācijas. 
2014. gada noteikumu punktā "Objektivitāte” bija iekḷauti četri apakšpunkti, bet 2020. gada noteikumos ir tikai divi. Tomēr satura ziṇā būtiskas izmaiņas nav veiktas, jo 2020. gada noteikumu punktā "Objektivitāte" iekḷautie apakšpunkti ir apjomīgāki un dal̦a no 2014. gada noteikumu punktā "Objektivitāte" iekḷautās informācijas ir atspoguḷota 2020. gada noteikumu nodal̦ās "Darbības, kas vērstas uz interešu konflikta novēršanu" un "Uzvedības noteikumi komunikācijā ar lobētājiem".

Kaut arī 2014. gada noteikumu punktā "Profesionalitāte" un 2020. gada noteikumu punktā "Profesionalitāte" skaitliski ir iekḷauts vienāds apakšpunktu skaits - četri -, tomēr saturiski tie ir mainījušies. 2014. gada noteikumu 6.2.2. apakšpunktā iekḷautā prasība Valsts policijas darbiniekiem savstarpēji sadarboties, kā arī 6.2.3. apakšpunktā minētā prasība pastāvīgi apgūt papildu profesionālās zināšanas 2020. gada noteikumos ir kḷuvušas par "Valsts policijas vērtībām" (sīkāk sk. šì raksta nodaḷā "Valsts policijas vērtības") un ieklautas punktos ar nosaukumu "Sadarbība" un "Attīstība".

2020. gada noteikumu punktā "Godprātība" iekḷauto apakšpunktu skaits, salīdzinot ar 2014. gada noteikumiem, ir pieaudzis. Ir uzlabojies un kḷuvis precīzāks šo apakšpunktu saturs. 2020. gada noteikumu 11.2.3. apakšpunktā ietvertā prasība informēt (celt trauksmi) par iespējamiem pārkāpumiem, ko policijas darbinieks ir novērojis, pildot dienesta (amata, darba) pienākumus, saskan ar Iekšlietu ministrijas sistēmas iestāžu un Ieslodzījuma vietu pārvaldes amatpersonu ar speciālajām dienesta pakāpēm disciplināratbildības likuma $2 .^{1}$ panta piektajā dạ̦ā ietvertajiem pienākumiem "atturēt no dienesta disciplīnas pārkāpuma citu amatpersonu, veicot pasākumus pārkāpuma pārtraukšanai, kā arī nekavējoties informēt augstāku amatpersonu par notikušo dienesta disciplīnas pārkāpumu" [3].

2020. gada noteikumos, salīdzinot ar 2014. gada noteikumiem, nav mainījies apakšpunktu skaits punktā "Konfidencialitāte". Tomēr, veicot šo noteikumu salīdzinājumu, jākonstatē, ka 2020. gada noteikumos punktā "Konfidencialitāte" iekḷautā informācija kḷuvusi precīzāka. 2014. gada noteikumu 6.4.2. apakšpunktā iekḷautā prasība policijas darbiniekiem n,emt vērā to, ka, paužot informāciju vai viedokli saistībā ar Valsts policijas darbu, tie veido sabiedrības viedokli par Valsts policijas tēlu, ir atspoguḷota 2020. gada noteikumu punktā "Lojalitāte".

2020. gada noteikumu punktā "Atbildība" ieklauto apakšpunktu skaits, salīdzinot ar 2014. gada noteikumiem, līdzīgi kā punktā "Godprātība" pieaudzis no četriem līdz sešiem. N̦emot vērā, ka parasti tiesību normas tiek sarindotas prioritārā secībā, svarīgo pirmo vietu 2020. gada noteikumos ieñem apakšpunkts, kas nebija iekḷauts 2014. gada noteikumu redakcijā: "nodarbinātais dienesta (amata, darba) pienākumus pilda atbildīgi, rūpīgi un savlaicīgi, nodrošinot Valsts policijas darba efektivitāti un kvalitāti, apzinoties, ka ar savu darbību ietekmē kopīgo Valsts policijas darba rezultātu" [11]. Ne mazāk svarīgajā trešajā vietā ierindojas apakšpunkts, kas paredz, ka policijas darbinieks ar Valsts policijas mantu un citiem resursiem "rīkojas saudzīgi, ekonomiski un racionāli, nepiel̦aujot tās nozaudēšanu, bojāšanu vai izmantošanu savām vai citu personu privātām vajadzībām" [11]. Saturiski precīzāki kḷuvuši arī četri atlikušie apakšpunkti. 
2020. gada noteikumu nodaḷā "Vērtības un profesionālās ētikas pamatprincipi" tika iekḷauti punkti "Darbs sabiedrības labā” un "Lojalitāte", kā arī "Valsts policijas vērtības", kuri vecākajos normatīvajos aktos, kas noteica Valsts policijas darbinieka profesionālās ètikas normas, netika iekḷauti. Turpmākajās nodaḷās tiks analizēti 2020. gada noteikumos iekḷautie profesionālās ētikas pamatprincipi un vērtības.

\section{Profesionalitāte}

Valsts policijas 2020. gada 5. februāra iekšējos noteikumos Nr. 3 "Valsts policijas ètikas kodekss" kā viens no profesionālās ètikas pamatprincipiem ir iekḷauta profesionalitāte (11.1. punkts). Tā kā pašlaik minētais normatīvais akts nav publicēts un ir pieejams tikai Valsts policijas iekšējā tìklā, šeit tiks sniegts pilns analizējamās normas saturs:

"11.1.1. nodarbinātais savas kompetences, prasmes un zināšanas dienesta (amata, darba) pienākumu izpildē izmanto efektīvi un kvalitatīvi;

11.1.2. nodarbinātā rīcība, lēmumi un viedokḷi ir pamatoti un izsvērti, balstīti situācijas analīzē, objektīvos faktos un datos;

11.1.3. nodarbinātais dienesta (amata, darba) pienākumu izpildē pārṇem nozares labo praksi un starptautisko pieredzi;

11.1.4. nodarbinātais prot uzklausīt citu viedokli un konflikta situācijas risināt objektīvi, izvērtējot pušu argumentus un mēǵinot rast ātrāku konflikta risinājumu" [11].

Vienu no iespējamiem skaidrojumiem jēdzienam "profesionalitāte" zinātniskajā literatūrā sniedz Latviešu literārās valodas vārdnīca, kurā profesionalitāte tiek skaidrota kā "profesionālā meistarība jeb profesionālisms, kas savukārt tiek skaidrots kā nodarbošanās (ar ko) kā ar profesiju (pretstatā amatierismam)” [35, 398-399].

Likuma "Par policiju" 27. pants nosaka, ka "policijas darbinieks par prettiesisku rīcību ir atbildīgs normatīvajos aktos noteiktajā kārtībā" [5]. Analizējot tiesu praksi, jāsecina, ka, vērtējot policijas darbinieka rīcības atbilstību normatīvo aktu prasībām, tiesa atsaucas arī uz Valsts policijas ètikas kodeksa normām.

Piemēram, 2017. gada 26. septembra spriedumā Rīgas rajona tiesa, vērtējot personas A rīcību, kas, būdama valsts amatpersona, izdarīja tīšas darbības, kas acīmredzami pārsniegušas valsts amatpersonai ar likumu piešḳirto tiesību un pilnvaru robežas, radījušas būtisku kaitējumu ar likumu aizsargātām personas interesēm un ir saistītas ar vardarbību (Krimināllikuma 317. panta otrā daḷa), norādīja arī uz Valsts policijas ētikas kodeksa normu neievērošanu: "Izvērtējot apsūdzētā rīcību konkrētajā situācijā, tiesa atzīst apsūdzētā rīcību par neprofesionālu un neatbilstošu noteiktiem ètikas pamatprincipiem" [23]. Rīgas rajona tiesa nosprieda, ka minētajā gadījumā, pamatojoties uz Krimināllikuma 317. panta otro dalıu, persona A ir atzīstama par vainīgu noziedzīga nodarījuma izdarīšanā un ir sodāma ar piespiedu darbu uz 250 stundām, turklāt tai uz trīs gadiem ir atṇemtas tiesības ieṇemt noteiktus amatus Latvijas Republikas Iekšlietu ministrijas struktūrās. 
Papildus prettiesiskām darbībām, par kurām normatīvajos aktos noteiktajā kārtībā ir paredzēta atbildība, profesionālajā vidē pastāv arī citas negatīvas parādības. Tiesību zinātnieks A. Matvejevs kā vienu no šādām problēmām nosauc korporatīvās morāles veidošanos pēc profesionālās darbinieku grupas interesēm. Viņš uzskata, ka tā ir morālo prasību profesionālās pārveidošanas galējā forma - deformācija. Viṇš arī norāda, ka "ḷoti bieži profesionālās grupas korporatīvās intereses neatbilst sabiedrības, cilvēku grupas vai indivīda interesēm un ir pretrunā ar tām" [39, 13]. Šìs problēmas neitralizācijai A. Matvejevs piedāvā veikt policijas darbinieku izglītošanu, īpašu uzmanību pievēršot tās intensitātei un saturam.

Krievijas zinātnieku pētījumos korporatīvā morāle tiek definēta kā lojalitāte attiecībā pret organizāciju, paklausība un centīgums, kā rezultātā korporācijā var izveidoties stingra birokrātijas sistēma [44, 105]. Kopsakarībā ar jēdzienu "korporatīvā morāle" tiek lietots jēdziens "korporatīvā solidaritāte" jeb "kopības gars" (franču val. esprit de corps). Korporatīvā solidaritāte tiek definēta kā sociālkulturāla parādība, kas pastāv vienā atsevišķā vienībā (organizācijā, atsevišķāa ekonomiskā subjektā utt.) kā apziņas fenomens, kas izpaužas vienas vienotas kopības veidošanā un gatavībā veikt aktīvu darbību, aizstāvot korporācijas intereses [43, 97]. Krievijas zinātniece J. Koršunova (E. А. Коршунова) norāda, ka korporatīvajai solidaritātei ir divi izpausmes veidi - individuālais un kolektīvais. Gan korporatīvajai solidaritātei, gan korporatīvajai morālei ir arī pozitīvās izpausmes. Ir pozitīvi vērtējama policijas darbinieku rīcība gadījumos, kad tie apvienojas Valsts policijas darbības mērḳu sasniegšanai, piemēram, lai veiktu individuālus vai kolektīvus preventīvus pasākumus.

\section{Godprātība}

Valsts policijas ētikas kodeksā kā viens no profesionālās ètikas pamatprincipiem ir iekḷauta godprātība, kas 11.2. punktā tiek skaidrota šādi:

\footnotetext{
“11.2.1. nodarbinātais dienesta (amata, darba) pienākumus pilda godprātīgi - godīgi, atklāti un patstāvīgi, ievērojot normatīvos aktus un ētikas normas, neizmantojot amata (dienesta) stāvokḷa priekšrocības personīgā labuma gūšanai sev vai citai personai vai lai ietekmētu citas iestādes vai personas, risinot personīgos jautājumus;

11.2.2. nodarbinātais dienesta (amata, darba) pienākumus pilda, vairojot sabiedrības uzticību Valsts policijai, un atturas no darbībām, kas var radīt aizdomas par negodprātīgu rīcību vai ietekmējamu stāvokli un darbībām, kas varētu ietekmēt lēmuma pieñemšanu;

11.2.3. nodarbinātais, ja tā rīcībā ir konkrēti fakti un pamatojums, saskaṇā ar noteikto kārtību informē (ceḷ trauksmi) par iespējamiem pārkāpumiem, ko novēro, pildot dienesta (amata, darba) pienākumus, kā arī cien,pilni izturas pret nodarbinātajiem, kuri cel̦ trauksmi" [11].
}

Latviešu literārās valodas vārdnīcā jēdziens "godprātīgs" ir skaidrots šādi: "tāds, kam raksturīgs godīgums, apzinīgums” [31, 112]. 
Godprātība un policijas darbinieka rīcības atbilstība prasībai vairot sabiedrības uzticību Valsts policijai tika analizēta vairākos tiesas spriedumos. Piemēram, Kurzemes apgabaltiesas Krimināllietu tiesas kolēgija 2016. gada 11. marta spriedumā atzina, ka "pirmās instances tiesa pamatoti norādījusi, ka /pers. H/ ir policijas darbinieks un viña pienākumos ietilpst novērst noziedzīgus nodarījumus un citus likumpārkāpumus, .. ka apsūdzētā rīcība, pašam izdarot noziedzīgu nodarījumu, ir vērtējama izteikti negatīvi. Apsūdzētais ir pārkāpis gan Valsts policijas ètikas kodeksā noteiktās vispārējās uzvedības normas, gan radījis sabiedrības negatīvu priekšstatu un neuzticēšanos policijai kā tiesībsargājošai institūcijai, /pers. H/ noziedzīgās darbības ir radījušas lielāku kaitējumu nekā /pers. I/ nodarījums, līdz ar to /pers. H/ galīgais sods pamatoti nosakāms bargāks salīdzinājumā ar /pers. I/" [20].

Vērtējot Valsts policijas ētikas kodeksa normu neievērošanu gadījumā, kad persona A, būdama valsts amatpersona, izmantojot savu dienesta stāvokli, pieprasīja un pieñēma no personas B materiālas vērtības - naudu - pirms likumīgas darbības neizdarǐšanas personas B interesēs (kukuḷnemšana), Rīgas pilsētas Latgales priekšpilsētas tiesa norādijja, ka "policijas darbiniekam amata pienākumi ir jāpilda likumīgi un godprātīgi, un jārīkojas tā, lai veicinātu Valsts policijas tēla stiprināšanu un sabiedrības uzticību" [22].

Līdzīgi, vērtējot gadījumu, kad persona B, būdama policijas darbinieks, izdarīja noziedzīgu nodarījumu, kas minēts Krimināllikuma 317. panta "Dienesta pilnvaru pārsniegšana" otrajā dạ̦ā, Kurzemes rajona tiesa norādīja, ka "/pers. B/ rīcība radīja sabiedrībā negatīvu iespaidu par policijas darbinieku ētiku, diskreditēja Latvijas valsti, Valsts policiju un negatīvi ietekmēja Valsts policijas prestižu" [21].

Šo un vairāku citu tiesas spriedumu analīze ḷauj secināt, ka policijas darbinieka izdarìtais noziedzīgais nodarījums ir rīcība, kas rada negatīvu sabiedrības priekšstatu un neuzticēšanos gan Valsts policijai kā tiesībsargājošai institūcijai, gan visai valsts pārvaldei kopumā.

\section{Objektivitāte}

Valsts policijas 2020. gada 5. februāra iekšējos noteikumos Nr. 3 "Valsts policijas ètikas kodekss" kā viens no profesionālās ètikas pamatprincipiem ir objektivitāte, kas 11.3. punktā tiek skaidrota šādi:

“11.3.1. nodarbinātais dienesta (amata, darba) pienākumus pilda objektīvi un taisnīgi, ar augstu tiesisko apziṇu, ievērojot personu vienlīdzību, un neizrādot ìpašu labvēlību vai radot nepamatotas privilēgijas kādai personai;

11.3.2. nodarbinātais, sagatavojot vai pieņemot lēmumu, ņem vērā tikai pārbaudītu un objektīvu informāciju, pamatojoties uz dokumentiem un iegūtajiem pierādījumiem un rīkojas saskaṇā ar normatīvajiem aktiem un vispārējiem tiesību principiem" [11].

Vārdam "objektīvs" ir vairākas nozīmes: "1) tāds, kas eksistē neatkarīgi no cilvēka apzinnas un atrodas ārpus tās; 2) tāds, kura uzskati, rīcība, runa atbilst īstenībai, tāds, kura uzskatos nav subjektīvas attieksmes, aizspriedumu" [34, 37-38]. 
Papildus iepriekšèjā apakšnodaḷā minētajam godprātības pamatprincipam tiesas savos spriedumos vērtēja arī objektivitātes pamatprincipa neievērošanu. Piemēram, Administratīvā apgabaltiesa ar 2016. gada 10. novembra [19] un 2017. gada 6. marta [18] spriedumu noraidija divu bijušo policijas darbinieku pieteikumus par Iekšlietu ministrijas 2015. gada 20. aprīla lēmumu Nr. 1-66/15 un Nr. 1-66/16 atcelšanu. Ar šiem Iekšlietu ministrijas lēmumiem bija atstāti negrozìti Valsts policijas lēmumi par diviem Valsts policijas Latgales reğiona pārvaldes policijas darbiniekiem piemērotiem disciplinārsodiem. Abi darbinieki tika atval̦ināti no dienesta par to, ka "2015. gada 9. janvārī, pildot dienesta pienākumus, personai (kas bija kolēga dēls) nenoformēja administratīvā pārkāpuma protokolu par transportlīdzekḷa vadī̌anu bez transportlīdzekḷa vadīšanas tiesībām" [17]. Šì rīcība bija vērtēta kā vairāku tiesību normu pārkāpums, tostarp 2014. gada 16. septembra noteikumu Nr. 36 "Valsts policijas ètikas kodekss" 6.1.1. apakšpunkta (Valsts policijas amatpersona (darbinieks) .. vienmēr pieṇem lēmumus atbilstoši normatīvo aktu prasībām un ievērojot visu personu vienlīdzību), 6.1.2. apakšpunkta (pildot dienesta (darba) pienākumus nerīkojas kādas personas interesēs) un 6.3.2. apakšpunkta (nepiel̦auj tādu izturēšanos un uzvedību, kas var radīt aizdomas par negodprātīgu rīcību vai ietekmējamu stāvokli) [10]. Šo ètikas pamatprincipu saturs nav zaudējis savu nozīmi un aktualitāti, arī pien,emot jauno Valsts policijas ètikas kodeksu.

\section{Darbs sabiedrības labā}

Nākamais Valsts policijas ētikas kodeksā iekḷautais profesionālās ētikas pamatprincips ir darbs sabiedrības labā, un 2020. gada noteikumu 11.4. punktā tas tiek skaidrots šādi:

"11.4.1. nodarbinātais rīkojas sabiedrības interesēs, panākot iespējami lielu labumu valstij un sabiedrībai;

11.4.2. nodarbinātais ievēro visu sabiedrības locekḷu līdztiesīgumu un taisnīguma principu, rodot taisnīgus un samērīgus risinājumus;

11.4.3. nodarbinātais, pildot dienesta (amata, darba) pienākumus, ievēro tiesiskuma un politiskās neitralitātes principu, kā arī pamatojas uz profesionāliem kritērijiem neatkarīgi no savas politiskās pārliecības" [11].

Šìs normas saturā ir iekḷauta atsauce uz vairākiem citiem principiem: līdztiesīgumu (jeb vienlīdzību likuma un tiesas priekšā), taisnīgumu, tiesiskumu un politisko neitralitāti. Nosauktie principi ir atspoguḷoti vairākos normatīvajos aktos, kas ir svarīgi Valsts policijas darbības nodrošināšanai, sākot ar Latvijas Republikas Satversmi un beidzot ar likumu "Par policiju".

Latvijas Republikas Satversmes 91. pants nosaka, ka "visi cilvēki Latvijā ir vienlīdzīgi likuma un tiesas priekšā" [1]. Skaidrojot šo normu kā tiesību zinātnieks, Latvijas Republikas Valsts prezidents Egils Levits secināja, ka "nevienlīdzīga attieksme ir jāattaisno. Ja šāds attaisnojums nav piel̦aujams vai nav pietiekams, tad vienlīdzības princips ir pārkāpts" [38, 88]. 
Arī Augstākās tiesas Senāts "vērš uzmanību, ka, ievērojot tiesiskās vienlīdzības principu, kā arī tiesības uz taisnīgu tiesu, tiesai būtu jāpieliek pūles, lai līdzīgi gadījumi (vai, vēl jo vairāk identiski, gadījumi) tiktu izlemti līdzīgi, jo procesa dalībniekiem ir tiesības sagaidìt un paḷauties, ka tie tiesā saṇems vienādu taisnību visos līdzīgos gadījumos" [13]. Atsaucoties uz amerikāṇu filozofa Džona Rolsa (John Rawls) teikto, tiesību zinātnieks Egils Levits norādỉja, ka "vienlīdzība ir centrālā taisnīguma sastāvdaḷa" [38, 75], un secināja, ka "dažkārt starp abiem principiem netiek pietiekami skaidri izšḳirts, daḷēji šie abi jēdzieni pat tiek lietoti kā sinonīmi” [38, 75].

Latviešu literārās valodas vārdnīcā jēdziens "taisnīgums" skaidrots šādi: "Ar cilvēka būtību, viṇa tiesībām saistīta atbilsme starp indivīda darbību, stāvokli sabiedrībā un to sociālo vērtējumu" [37, 430].

Taisnīguma ievērošana, īstenojot policijas darbību, ir pieprasìta arī likumā "Par policiju", kur 5. pantā ir noteikts, ka "policijas darbība tiek organizēta, ievērojot likumību, humānismu, cilvēka tiesības, sociālo taisnīgumu, atklātumu, vienvadību un balstoties uz iedzīvotāju palīdzību" [5]. Policijas darbība notiek, pamatojoties uz likumu: uz Latvijas Republikas Satversmi, uz saistībām, kas izriet no starptautiskajiem līgumiem, deklarācijām un konvencijām, uz likumu "Par policiju", kā arī uz citiem Latvijas Republikas normatīvajiem aktiem.

Augstākās tiesas Senāts secināja, ka "tiesību virsvadības princips (angḷu val. rule of law) un no tā atvasinātais tiesiskuma princips noteic, ka iestādes rīcībai pēc būtības ir jāatbilst tiesību normām (turklāt tas nozīmē ne tikai rakstītās tiesību normas, bet arī vispārējos tiesību principus). Līdz ar to tiesiskuma princips paredz tiesību piemērotāja pienākumu izprast tiesību sistēmu (tostarp tiesību normu hierarhiju) un tiesību sistēmas pamatā esošos tiesību principus un konstitucionāla ranga vērtības (tātad arī cilvēktiesības), un piemērot tiesību normas, noskaidrojot to jēgu un mērḳi šis tiesību sistēmas kontekstā" [14]. Minētais neapšaubāmi ir saistošs policijas darbiniekiem kā tiesību piemērotājiem un nosaka, ka viṇiem ir jāiegūst visas nepieciešamās zināšanas un prasmes, lai spētu piemērot un interpretēt tiesību normas.

Eiropas Savienībā par visefektīvāko policijas darbības metodi ir atzìts uz sabiedrību vērsts policijas darbs (angḷu val. community policing) [41, 7]. Policija aktīvi sadarbojas ar sabiedrību, risinot ar noziedzību un sabiedriskās kārtības traucējumiem saistītās problēmas [26,3]. Minētā prasība ir nostiprināta arī normatīvi - likuma "Par policiju" 7. pants nosaka, ka "policija sadarbojas ar iestādēm, privātpersonām un personu apvienībām" [5].

Mācību grāmatā, kas paredzēta jaunpien,emtajiem policijas darbiniekiem, ir uzsvērts, ka "policijas darbības efektivitāte tiek nodrošināta, izmantojot trīs komponentus: (1) sadarbība ar sabiedrību; (2) problēmu risināšana, nevis tikai seku likvidēšana; un (3) organizācijas reorganizācija, decentralizējot lēmumu pien̦emšanas struktūras" [40, 31].

Lai izveidotu sadarbỉbu ar sabiedrību, policijai ir:

1) jābūt pamanāmai un pieejamai sabiedrībai;

2) jābūt sabiedrībai zināmai;

3) jāreagēe uz sabiedrības vajadzībām; 
4) jāuzklausa sabiedrības rūpes;

5) jāaktivizē un jāmobilizē sabiedrības grupas;

6) jāatbild par savām aktivitātēm un šo aktivitāšu rezultātiem [27, 13].

Valsts policijas attīstības koncepcijā par vienu no attīstības virzieniem tika izvirzīta likumpārkāpumu novēršana, un viens no stratēgiskajiem mērḳiem bija "veicināt sabiedrības drošības apdraudējumu un likumpārkāpumu efektīvāku novēršanu, attīstot ciešāku sadarbību ar likumpārkāpumu novēršanā līdziesaistìtajām institūcijām un organizācijām, sabiedrību kopumā un atseviškām tās grupām un indivīdiem un paplašinot un prioritizējot Valsts policijas praksi un aktivitātes likumpārkāpumu prevencijā” [7]. Šim attīstības virzienam ir četri apakšvirzieni: 1) uz sabiedrību vērsta policijas darba pieejas ieviešana; 2) policijas darba ar cietušajiem attīstī̌sana; 3) policijas redzamības nodrošināšana; 4) policijas pieejamība iedzīvotājiem. Likumpārkāpumu novēršana ir viens no svarīgākajiem Valsts policijas uzdevumiem, ìstenojot darbu sabiedrības labā.

\section{Konfidencialitāte}

Valsts policijas 2020. gada 5. februāra iekšējos noteikumos Nr. 3 "Valsts policijas ètikas kodekss" kā viens no profesionālās ētikas pamatprincipiem ir konfidencialitāte, kas 11.5. punktā tiek skaidrota šādi:

\footnotetext{
"11.5.1. nodarbinātais informāciju, kas kḷuvusi zināma, pildot dienesta (amata, darba) pienākumus, izmanto, apstrādā un glabā saskaṇā ar normatīvajiem aktiem un noteiktās informācijas veida lietošanas noteikumiem;

11.5.2. nodarbinātais informāciju, kas kḷuvusi zināma, pildot dienesta (amata, darba) pienākumus, neatklāj citiem, tai skaitā, arī citiem nodarbinātajiem, kuriem šì informācija nav nepieciešama dienesta (amata, darba) pienākumu pildīšanai, un neizmanto personiskās interesēs" [11].
}

Konfidencialitāte Akadēmiskajā terminu datubāzē tiek skaidrota kā "statuss, kas nosaka, ka attiecīgā informācija nav pieejama vai netiek izpausta nepiederošām personām, juridiskām personām vai procedūru ietvaros" [24].

Valsts policijas 2005. gada 31. maija noteikumu Nr. 1 "Valsts policijas darbinieka profesionālās ētikas un uzvedības kodekss" 15. punkts noteica, ka "policijas darbinieks neizpauž vin,am zināmo dienesta informāciju, izn,emot likumos noteiktos gadijumos" [9]. Komentējot šo punktu un citu normatīvo aktu darbību, Latvijas Republikas Augstākās tiesas Senāta Administratīvo lietu departaments secinājis, ka ne likuma "Par policiju" 6. panta trešã daḷa, kas nosaka, ka "policijai aizliegts izpaust ziñas, kuras aizskar cilvēku personisko dzīvi, kā arī fizisko un juridisko personu godu un ciennu, ja šì darbība nenotiek tiesiskās kārtības nostiprināšanas un izmeklēšanas interesēs" [5], ne Valsts policijas 2005. gada 31. maija noteikumu Nr. 1 "Valsts policijas darbinieka profesionālās ētikas un uzvedības kodekss" 15. punkts nav absolūts. Tiesa norādīja, ka "var būt gadījumi, kad arī ierobežotas pieejamības informāciju var izpaust, ja tam ir leǵitīms mērḳis un sabiedrības interese iegūt šo informāciju ir lielāka nekā personas tiesības uz attiecīgās informācijas 
Ēriks Trels. Valsts policijas darbinieka profesionālās ētikas pamatprincipi

neizpaušanu" [15]. Šo atzinumu var attiecināt arī uz 2020. gada 5. februārī pieṇemtajiem Valsts policijas iekšējiem noteikumiem Nr. 3 "Valsts policijas ētikas kodekss".

\section{Atbildība}

Valsts policijas ētikas kodeksā kā viens no profesionālās ētikas pamatprincipiem ir ieklauta atbildỉba, kas 11.6. punktā tiek skaidrota šādi:

"11.6.1. nodarbinātais dienesta (amata, darba) pienākumus pilda atbildīgi, rūpīgi un savlaicīgi, nodrošinot Valsts policijas darba efektivitāti un kvalitāti, apzinoties, ka ar savu darbību ietekmē kopīgo Valsts policijas darba rezultātu;

11.6.2. nodarbinātais pieṇem skaidrus un pamatotus lēmumus un uzṇemas atbildibu par tiem;

11.6.3. nodarbinātais ar Valsts policijas īpašumā, valdījumā vai lietošanā esošu mantu un citiem resursiem rīkojas saudzīgi, ekonomiski un racionāli, nepieḷaujot tās nozaudēšanu, bojāšanu vai izmantošanu savām vai citu personu privātām vajadzībām;

11.6.4. nodarbinātais, saṇemot prettiesisku pavēli vai rīkojumu, ziṇo amatā augstākai amatpersonai;

11.6.5. nodarbinātais sniedz patiesu informāciju;

11.6.6. nodarbinātais ir paškritisks, atzīst un labo savas kḷūdas un atvainojas par neētisku rīcību" [11].

Zinātniskajā literatūrā atbildība tiek skaidrotā kā attieksme, kam raksturīgas rūpes un pienākuma apziņa [29, 342].

Likuma "Par policiju" 27. pants nosaka, ka "apzināta nelikumīgas pavēles vai rīkojuma izpildīšana neatbrīvo policijas darbinieku no atbildības" [5]. Analizējot abos normatīvajos aktos ietvertās normas, jāsecina, ka nodarbinātajam prettiesiska pavēle vai rīkojums nav jāpilda un par tās saṇemšanu ir jāziṇo amatā augstākai amatpersonai.

Turklāt likuma "Par policiju" 27. pantā ir noteikts, ka "policijas darbinieks par prettiesisku rīcību ir atbildīgs normatīvajos aktos noteiktajā kārtībā” [5]. Šì normas piemērošanas atspoguḷojums ir atrodams visos rakstā analizētajos tiesas spriedumos.

\section{Lojalitāte}

Līdz 2020. gada 5. februārim lojalitāte kā profesionālās ētikas pamatprincips nebija iekḷauta Valsts policijas iekšējā normatīvajā regulējumā. Jaunajā Valsts policijas ētikas kodeksā šis princips ir iekḷauts 11.7. punktā un tiek skaidrots šādi:

"11.7.1. nodarbinātais, pildot dienesta (amata, darba) pienākumus, valsts intereses vienmēr uzskata par primārām attiecībā pret personiskām interesēm;

11.7.2. nodarbinātais publiskos izteikumos ir lojāls pret valsti un Valsts policiju un ievēro Valsts policijas darbības mērḳi un pamatvērtības;

11.7.3. nodarbinātais ar profesionālo darbību saistītos publiskos izteikumos paskaidro vai pauž Valsts policijas viedokli, apzinoties, ka veido sabiedrības viedokli par Valsts policijas tēlu; 
11.7.4. nodarbinātais nepiedalās aktivitātēs, kas objektīvi varētu radīt šaubas par rīcību valsts vai sabiedrības interesēs, traucēt profesionāli pildìt dienesta (amata, darba) pienākumus, kompromitēt vai apkaunot Valsts policiju. Valsts policija respektē nodarbināto privātumu un neierobežo to privātās aktivitātes ārpus darba laika, ciktāl tas neasociējas ar Valsts policiju" [11].

Latviešu literārās valodas vārdnīcā vārdam "lojalitāte" ir divi skaidrojumi: “(1) izturēšanās, rīcība, kurā izpaužas respekts pret pastāvošo varu, tās likumu ievērošana; (2) izturēšanās, rīcība, kurā izpaužas godprātīga, korekta, cieṇas pilna attieksme (pret ko)" $[32,738]$.

Tā kā lojalitātes pamatprincips Valsts policijas normatīvajā regulējumā tika iekḷauts tikai 2020. gada 5. februārī, tiesu prakse, kurā būtu vērtējama šì principa neievērošana, nav izveidojusies.

\section{Valsts policijas vērtības}

Papildus Valsts policijas 2020. gada 5. februāra iekšējos noteikumos Nr. 3 "Valsts policijas ētikas kodekss" minētajiem profesionālās ètikas pamatprincipiem ir noteikts, ka nodarbinātajam jārīkojas saskaṇā ar šādām Valsts policijas vērtībām: piederību, sadarbību, attīstību, cieṇu un komunikāciju. 2020. gada 5. februāra iekšējos noteikumos Nr. 3 "Valsts policijas ètikas kodekss" jēdziens "piederība" tiek skaidrots šādi:

"12.1. piederība - sevis apzināšanās kā daḷu no Valsts policijas un lepošanās ar piederību Valsts policijai" [11].

Latviešu literārās valodas vārdnīcā vārdam "piederība" ir vairāki skaidrojumi: "(1) stāvoklis, attieksme, kam ir raksturīgas ciešas saiknes (ar ko): (2) stāvoklis, kad (kas) ir iekḷauts (kādā sistēmā, klasifikācijas grupā u. tml.); (3) stāvoklis, kad (kādam) ir ỉpašuma tiesības (uz ko), kad (kas) ir (kāda) ìpašumā" [35, 27].

Savukārt Valsts policijas vērtība "sadarbība" tiek skaidrota šādi:

“12.2. sadarbība - godīga, atklāta, cien,pilna, uz risinājumu vērsta komunikācija un informācijas apmaiña ar citiem nodarbinātajiem un iestādēm, sniedzot vai saṇemot nepieciešamo palīdzību pienākumu izpildē, iesaistī̌sanās jautājumu risināšanā, kas skar vairākas Valsts policijas struktūrvienības, vairākas iestādes vai nozares un atvērtība sadarbības iniciatīvām ar citu jomu speciālistiem, kā arī vienota mērḳu izpratne un to sasniegšana" [11].

Latviešu literārās valodas vārdnīcā vārda "sadarbība" definīcija ir šāda: "kopīga darbība; saskan,ota savstarpēja darbỉba, arī palīdzība" [36, 61].

Valsts policijas vērtîba "attīstība" Valsts policijas ētikas kodeksā tiek skaidrota šādi:

"12.3. attīstība - pastāvīga savu kompetenču, prasmju un zināšanu pilnveidošana, atvērtība pārmaiṇām, iesaistīšanās jaunu pieeju un inovāciju izmantošanā un ieguldījums Valsts policijas attīstībā" [11]. 
Latviešu literārās valodas vārdnīcā vārdam "attīstība" ir vairāki skaidrojumi: “(1) neatgriezeniska norise (dabā), kurā rodas kvalitatīvas izmaiṇas; (2) garīgā veidošanās, nobriešana, izaugsme; arī (spēju, jūtu u. tml.) izveide; (3) jaunas kvalitātes rašanās, pāreja augstākā pakāpē, plašāka apjoma sasniegšana, pilnveidošanās (sabiedrības dzīvē, zinātnē, mākslā u. tml.); (4) gaita, norise (notikumam, darbỉbai, procesam). Risinājums (sižetam)" [29, 467].

Jēdziens "cien,a" Valsts policijas ètikas kodeksā tiek skaidrots šādi:

"12.4. cieṇa - attieksme, kam raksturīga citu personību spēju, zināšanu un vērtību atzīšana, kas izpaužas kā cieṇpilna komunikācija ar citiem nodarbinātajiem, iestādēm, organizācijām, komersantiem un ikvienu sabiedrības locekli, prasme uzklausīt citu viedokli, bet viedokḷu nesakritības gadījumā sniegt objektīvus un korektus argumentus" [11].

Arī Latviešu literārās valodas vārdnīcā jēdzienam "cieṇa" ir vairāki skaidrojumi: "(1) attieksme, kurai ir raksturīga (kāda cilvēka) spēju, zināšanu, nopelnu, vērtības u. tml. atzīšana; šādas attieksmes izpausme; (2) morālā vērtība, morālā stāja, arī gods; (3) savas vērtības, tiesību apzina; šĩs apzinas izpausme" [30, 179-180].

2020. gada 5. februāra iekšējos noteikumos Nr. 3 "Valsts policijas ètikas kodekss" jēdziens "komunikācija" tiek skaidrots šādi:

"12.5. komunikācija - godīga, atklāta, laipna, uz risinājumu vērsta sazināšanās ar citiem nodarbinātajiem, iestādēm, organizācijām, komersantiem un ikvienu sabiedrības locekli" [11].

Ilustrētajā svešvārdu vārdnīcā jēdziens "komunikācija" (latīnuu val. communicatio ziņojums) tiek skaidrots šādi: "(1) sakari, sakaru sistēma, vadu sistēma (elektriskās strāvas, ūdens, gāzes pārvadei, kanalizācijai); satiksmes ceḷi; (2) sazināšanās, informācijas pārraide; (3) saskarsme, saziṇa; domu, priekšstatu, jūtu u. c. apmaiņa starp cilvēkiem viṇu darbības procesā; (4) satiksmes ceḷi, kas karaspēka izvietojumu rajonu saista ar bāzēm un aizmugures rajoniem" [28, 376].

Savukārt Latviešu literārās valodas vārdnīcā jēdzienam "komunikācija" ir divi skaidrojumi: "(1) sakari, sakaru sistēma (kādu signālu pārraidei); vadi, vadu sistēma (elektriskās strāvas, ūdens, gāzes pārvadei, kanalizācijai); satiksmes ceḷi; (2) sazināšanās; informācijas pārraide" [32, 326]. Valodniecības pamatterminu skaidrojošajā vārdnīcā komunikācija tiek skaidrota kā "informācijas vai domu apmaiņa starp personām; informācijas forma, kurā izmanto valodu vai citas zīmes; sazināšanās, sakari; saskarsme”, bet "valodniecībā - sazināšanās, izmantojot valodu" [42, 344].

Rakstā analizēto jēdzienu skaidrojumi ataino, ka profesionālās ètikas pamatprincipi un vērtības var tikt skaidrotas un izprastas dažādi, tādēḷ var rasties atšḳirīga interpretācija. Lai to nepiel̦autu, būtu lietderīgi pilnvarot Valsts policijas Ētikas komisiju nepieciešamības gadijumā sniegt Valsts policijas ētikas kodeksa normu skaidrojumu. 


\section{Secinājumi un priekšlikumi}

Normatīvais regulējums, kas nosaka Valsts policijas darbinieka profesionālās ètikas normas, tostarp vērtības un profesionālās ètikas pamatprincipus, vēsturiski attīstoties, ir uzlabojies. Pozitīvi vērtējams tas, ka normu saturs kḷuvis skaidrāks. Tas atvieglo darbu tiesību piemērotājam, jo, kā atzina romiešu juristi, clara non sunt interpretanda (latinnu val. 'skaidri likumi nav jāinterpretē').

Valsts policijas ètikas kodeksā ir atrunāts, ka tas nav visaptverošs ētikas vērtību, pamatprincipu un vispārējās uzvedības noteikumu apraksts, kā arī ir noteikts, ka gadījumos, kad rīcība konkrētajā situācijā nav izskaidrota kodeksa normās, nodarbinātajam jārīkojas saskaṇā ar vispārējiem sabiedrības ètikas principiem un uzvedības normām.

Lai nepiel̦autu Valsts policijas ētikas kodeksa normu atšḳirīgu interpretāciju un izvērtētu nodarbinātā rīcības atbilstību vispārējiem sabiedrības ètikas principiem un uzvedības normām, būtu lietderīgi veikt grozījumus Valsts policijas Ētikas komisijas nolikumā, papildinot 2. nodal̦as "Komisijas uzdevumi un tiesības" 5. punktu (komisijas uzdevumi) ar 5.7. apakšpunktu šādā redakcijā: "sniegt Valsts policijas ètikas kodeksa normu skaidrojumu" un 5.8. apakšpunktu šādā redakcijā: "izvêrtēt nodarbinātā rīcības atbilstību vispārējiem sabiedrības ètikas principiem un uzvedības normām gadījumos, kad tā nav atrunāta Ëtikas kodeksa normās".

Valsts policijas darbinieka profesionālās ètikas pamatprincipu un Valsts policijas vērtību saturs, kā arī iepriekšējos gados pieņemtie tiesas spriedumi, kas tika analizēti šajā rakstā, ḷauj prognozēt, ka arī turpmāk tiesa savos spriedumos, kā arī Iekšlietu ministrija un Valsts policija savos lēmumos, vērtējot policijas darbinieku rīcību, turpinās plaši izmantot normatīvo regulējumu, kas nosaka Valsts policijas darbinieka profesionālās ètikas normas. Tas norāda uz nepieciešamību Valsts policijas nodarbinātajiem apgūt Valsts policijas ētikas kodeksa normas, lai nepiel̦autu to pārkāpumu. Būtu lietderīgi Valsts policijas darbinieku apmācībai Valsts policijas koledžā un Rīgas Stradiṇa universitātē izstrādāt un īstenot pieaugušo neformālās izglìtības programmu "Valsts policijas darbinieka profesionālās ètikas pamatprincipi".

\section{Basic Principles of the Professional Ethics of State Police Officers}

\section{Abstract}

On 5 February 2020, in Latvia, has adopted a Code of Ethics for the State police. This Code, on top of everything else, shall define the basic principles of the professional ethics to be observed by the State Police personnel performing their official duties, as well as beyond the place and time of service. 
The article aims to initiate a debate on potential problems related to the application of the new regulatory framework.

The author offers his vision of the development a regulatory framework and how things have changed since 2005.

Keywords: State police, police officers, professional ethics, basic principles of the professional ethics.

\section{Avoti un literatūra}

\section{Tiesību akti}

1. Latvijas Republikas Satversme: Latvijas Republikas likums: stājās spēkā 07.11.1922. Latvijas Vēstnesis. 43, 01.07.1993.

2. Iekšlietu ministrijas sistēmas iestāžu un Ieslodzijuma vietu pārvaldes amatpersonu ar speciālajām dienesta pakāpēm dienesta gaitas likums: Latvijas Republikas likums: stājās spēkā 01.10.2006. Latvijas Vēstnesis. 101, 30.06.2006.

3. Iekšlietu ministrijas sistēmas iestāžu un Ieslodzījuma vietu pārvaldes amatpersonu ar speciālajām dienesta pakāpēm disciplināratbildības likums: Latvijas Republikas likums: stājās spēkāā 01.10.2006. Latvijas Vēstnesis. 101, 30.06.2006.

4. Krimināllikums: Latvijas Republikas likums: stājās spēkā 01.04.1999. Latvijas Vēstnesis. 199/200, 08.07.1998.

5. Par policiju: Latvijas Republikas likums: stājās spēkā 04.06.1991. Latvijas Republikas Augstākās Padomes un Valdỉbas Zinotäjs. 31/32, 15.08.1991.

6. Valsts pārvaldes iekārtas likums: Latvijas Republikas likums: stājās spēkā 01.01.2003. Latvijas Vēstnesis. 94, 21.06.2002.

7. Par Valsts policijas attīstības koncepciju: Ministru kabineta rīkojums Nr. 248: pieṇemts 06.04.2016. Latvijas Vēstnesis. 69, 11.04.2016.

8. Valsts pārvaldes vērtības un ētikas pamatprincipi: Ministru kabineta ieteikumi Nr. 1: pienememti 21.11.2018. Latvijas Vēstnesis. 235, 29.11.2018.

9. Valsts policijas darbinieka profesionālās ētikas un uzvedības kodekss: Valsts policijas noteikumi Nr. 1: pieṇemti 31.05.2005. un zaudēja spēku 16.09.2014. Iegūts no: http://www.vp.gov.lv/faili/ sadalas/policijas_darbinieka_etikas_kodekss.pdf [sk. 23.03.2020.].

10. Valsts policijas ētikas kodekss: Valsts policijas iekšèjie noteikumi Nr. 36: pien̦emti 16.09.2014. un zaudēja spēku 05.02.2020. Iegūts no: http://www.vp.gov.lv/faili/sadalas/etikas_kodekss.pdf [sk. 23.03.2020.].

11. Valsts policijas ētikas kodekss: Valsts policijas iekšējie noteikumi Nr. 3: pien̦emti 05.02.2020. Nav publicēts.

12. Valsts policijas Ētikas komisijas nolikums: Valsts policijas iekšējie noteikumi Nr. 4: pien̦emti 05.02.2020. Nav publicēts.

\section{Tiesu prakse}

13. Augstākās tiesas Senāta Administratīvo lietu departamenta 2019. gada 28. marta spriedums lietā Nr. A420425314, SKA-121/2019. 
14. Augstākās tiesas Senāta Administratīvo lietu departamenta 2019. gada 31. janvāra spriedums lietā Nr. A420322015, SKA-148/2019.

15. Augstākās tiesas Senāta Administratīvo lietu departamenta 2011. gada 31. janvāra spriedums lietā Nr. A42538107, SKA-103/2011.

16. Augstākās tiesas Administratīvo lietu departamenta 2016. gada 23. septembra spriedums lietā Nr. A420256715, SKA-1220/2016.

17. Augstākās tiesas Administratīvo lietu departamenta 2016. gada 8. jūlija spriedums lietā Nr. A420213415, SKA-1023/2016.

18. Administratīvās apgabaltiesas 2017. gada 6. marta spriedums lietā Nr. A420256715, AA43-0717-17/19.

19. Administratīiās apgabaltiesas 2016. gada 10. novembra spriedums lietā Nr. A420213415, AA43-2186-16/19.

20. Kurzemes apgabaltiesas Krimināllietu tiesas kolẹgijas 2016. gada 11. marta spriedums lietā Nr. 12360000413, KA02-0007-16/8.

21. Kurzemes rajona tiesas 2019. gada 13. marta spriedums lietā Nr. 11860005617, K69-0153-19/25.

22. Rīgas pilsētas Latgales priekšpilsētas tiesas 2018. gada 17. septembra spriedums lietā Nr. 11819000515, K29-67/18.

23. Rìgas rajona tiesas 2017. gada 26. septembra spriedums lietā Nr. 118190000915, K33-0642-17/10.

\section{Literatūra}

24. Akadēmiskā terminu datubāze $A$ kadTerm. Iegūts no: http://termini.lza.lv/term.php?term=kon fidencialit\%C4\%81te\&list=konfidencialit\%C4\%81te\&lang=LV [sk. 18.03.2020.].

25. Eiropas Padomes Pretkorupcijas starpvalstu grupas piektās novērtēšanas kārtas ziņojums. Iegūts no: https://www.knab.gov.lv/upload/international/21.08._v_novertesanas_kartas_zinojums.pdf [sk. 18.03.2020.].

26. Fridell, L. 2004. The Defining Characteristics of Community Policing. In: Fridell L., Wycoff M. A. eds. Community Policing: The Past, Present, and Future. Washington: Police Executive Research Forum, The Annie E. Casey Foundation, 3-12.

27. Good practices in building police-public partnerships. Vienna: Organization on Security and Cooperation in Europe, 2008.

28. Ilustrētā svešvārdu vārdnīca. 2005. Rīga: Avots.

29. Latviešu literārāas valodas vārdnīca. 1972. 1. sēj. Rīga: Zinātne.

30. Latviešu literārās valodas vārdnīca. 1973. 2. sēj. Rīga: Zinātne.

31. Latviešu literārās valodas vārdnīca. 1975. 3. sēj. Rìga: Zinātne.

32. Latviešu literārās valodas vārdnìca. 1980. 4. sēj. Rīga: Zinātne.

33. Latviešu literārās valodas vārdnīca. 1984. 5. sēj. Rīga: Zinātne.

34. Latviešu literārās valodas vārdnìca. 1986. 6. sēj., 1. daḷa. Rīga: Zinātne.

35. Latviešu literārās valodas vārdnīca. 1987. 6. sēj., 2. daḷa. Rīga: Zinātne.

36. Latviešu literārās valodas vārdnīca. 1989. 7. sēj., 1. daḷa. Rīga: Zinātne.

37. Latviešu literārās valodas vārdnīca. 1991. 7. sēj., 2. dạ̦a. Rīga: Zinātne.

38. Levits, E. 2011. Visi cilvēki Latvijā ir vienlīdzīgi likuma un tiesas priekšā. Cilvēka tiesības tiek īstenotas bez jebkādas diskriminācijas. No: Latvijas Republikas Satversmes komentāri. VIII nodaḷa. Cilvēka pamattiesības. Rīga: Latvijas Vēstnesis, 73-118. 
39. Matvejevs, A. 2019. Profesionālā ētika un policijas operatīvā darbība: vai pastāv kompromiss? Socrates. 1, 11-21.

40. Treḷs, Ė., Krutova, Ė. 2016. Policijas tiesības shēmās un tabulās. Rīga: Valsts policijas koledža.

41. Uz sabiedrību vērsts policijas darbs Latvijā 2009.-2012. Pieredze un nākamie soḷi. 2012. BērziṇaRuksere, I., Avota, I., Grūbis, N. u. c. Rīga: Valsts policija.

42. Valodniecības pamatterminu skaidrojošā vārdnīca. 2007. Rīga: Madonas poligrāfists.

43. Коршунова, Е. А. 2002. Корпорация и корпоративная солидарность: традиции, подходы, Российская действительность. Экономическая социология. Том 3, 1, 87-110.

44. Этика и психология профессиональной деятельности. 2019. ПоА реА. Е. И. Рогова. Москва: Юрайт. 